\title{
Antioxidant potential of oregano (Oreganum vulgare L.), basil (Ocimum basilicum L.) and thyme (Thymus vulgaris L.): application of oleoresins in vegetable oil
}

\author{
Potencial antioxidante de orégano (Oreganum vulgare L.), manjericão (Ocimum basilicum L.) e tomilho \\ (Thymus vulgaris L.): aplicação de oleorresinas em óleo vegetal
}

\author{
Patrícia Vieira DEL RÉ ${ }^{1}$ Neuza JORGE ${ }^{1 *}$
}

\begin{abstract}
Studies have been carried out in order to increase the stability of vegetable oils due to economic and health protection reasons. There is a growing interest in the addition of natural antioxidants; especially herbs and spices. For this reason, this study aimed at evaluating the antioxidant potential of the oleoresins of oregano, basil, and thyme, as well as their behavior when applied to soybean oil under various concentrations. Firstly, the antioxidant activity was determined by the $\beta$-carotene/linoleic acid system and by the quantification of total phenolic compounds. Next, different concentrations of oleoresins (500 to $3000 \mathrm{mg} \cdot \mathrm{kg}^{-1}$ ) were added to the soybean oil, and its antioxidant potential was analyzed using the oxidative stability through a Rancimat equipment. The value of $3000 \mathrm{mg} \cdot \mathrm{kg}^{-1}$ of thyme and oregano oleoresins was the concentration that presented the greatest oxidative stability to soybean oil making them a natural alternative to vegetable oil conservation.

Keywords: spice extracts; oxidation; induction period.
\end{abstract}

\begin{abstract}
Resumo
Por razões econômicas e de proteção à saúde, pesquisas têm sido dirigidas para ampliar a estabilidade dos óleos vegetais. Existe uma tendência para a adição de antioxidantes naturais, em particular, um crescente interesse em ervas e especiarias. Desta forma, os objetivos deste trabalho foram avaliar o potencial antioxidante das oleorresinas de orégano, manjericão e tomilho e seu comportamento ao serem aplicadas ao óleo de soja em diferentes concentrações. Numa primeira etapa foi determinada a atividade antioxidante pelo sistema $\beta$-caroteno/ácido linoleico e a quantificação de compostos fenólicos totais. Posteriormente, foram adicionadas ao óleo de soja diferentes concentrações das oleorresinas (500 a 3000 mg. $\mathrm{kg}^{-1}$ ) e analisado seu potencial antioxidante por meio da estabilidade oxidativa utilizando o Rancimat. A concentração de $3000 \mathrm{mg} \cdot \mathrm{kg}^{-1}$ das oleorresinas de orégano e tomilho foi a que apresentou melhor estabilidade oxidativa ao óleo de soja, o que as tornam alternativa natural na conservação de óleos vegetais.

Palavras-chave: extratos de especiarias; oxidação; período de indução.
\end{abstract}

\section{Introduction}

In food processing, many operations favor oxidation reactions. Among them, there is the possibility of free radicals reacting or interacting with other food components, which causes a decrease in the nutritional quality of these components. Oxidation is a spontaneous and unavoidable phenomenon. It has a direct implication in the commercial values of fatty compounds and their derivatives (NAWAR, 1996; SILVA; BORGES; FERREIRA, 1999).

The addition of antioxidant compounds is a current practice to delay undesirable alterations in oils avoiding or at least delaying rancidification. In Brazil, the use of synthetic antioxidants is controlled by the Ministry of Health, which limits maximum concentrations for butylhydroxyanisole (BHA) and tert-butylhydroquinone (TBHQ) as $200 \mathrm{mg} \cdot \mathrm{kg}^{-1}$, and for butylhydroxytoluene (BHT) and Propyl Gallate (PG) as $100 \mathrm{mg} \cdot \mathrm{kg}^{-1}$. Declaring the use of synthetic antioxidants on food label is mandatory (BRASIL, 2005).

Nowadays, many studies have been carried out aiming at the partial replacement of synthetic antioxidants for natural antioxidants due to the association of synthetic antioxidants with carcinogenic processes in experimental animals (GUNDUC; EL, 2003; SVILAAS et al., 2004).

Studies have indicated that the antioxidants BHA and BHT could present some toxicity and a lower effectiveness than some natural antioxidants (WANASUNDARA; SHAHIDI, 1998). Therefore, in the last few years, studies on possible antioxidants present in natural products have been emphasized, especially herbs and spices, which are used worldwide for culinary purposes. Their antioxidant properties are considered effective

Received 6/4/2010

Accepted 1/11/2010 (004778)

${ }^{1}$ Departamento de Engenharia e Tecnologia de Alimentos, Universidade Estadual Paulista - UNESP, CEP 15054-000, São José do Rio Preto, SP, Brasil,

e-mail:njorge@ibilce.unesp.br

${ }^{*}$ Corresponding author 
in delaying the lipid peroxidation process in oils and lipid foods. This fact has aroused interest of many research groups (MILOS; MASTELIC; JERKOVIC, 2000).

Various studies with different sources highlight the oxidation inhibition in vegetable oils or animal fats, among them are oregano (KIKUZAKI; NAKATANI, 1989; VEKIAKI et al., 1993), rosemary (RAMALHO, JORGE, 2006), ginger (ANDREO; JORGE, 2007), coriander (ANGELO; JORGE, 2008, MELO et al., 2003), basil, and thyme (LEE et al., 2005), and others. Their antioxidant power is attributed to phenolic compounds, tocopherols, carotenoids, and vitamin C.

Murcia, Jiménez and Mantínez-Tomé (2001) observed that the extracts of cumin, oregano, paprika, rosemary and saffron at a concentration of $5 \%$, presented protection activity against oxidation in edible oils similar to that of the synthetic antioxidants BHT, BHA, and propyl gallate at $100 \mu \mathrm{g} \cdot \mathrm{g}^{-1}$.

Therefore, this study aimed at evaluating the antioxidant potential of the extracts of spices (oregano, basil and thyme) as well as their behavior when applied to soybean oil under different concentrations.

\section{Material and methods}

\subsection{Material}

Extracts of oregano (Oreganum vulgare L.), basil (Ocimum basilicum L.) and thyme (Thymus vulgaris $\mathrm{L}$.), were used in form of oleoresins; they were supplied by Kalsec', and their components are described in Table 1. Refined soybean oil, free of synthetic antioxidants and citric acid, was supplied by Granol Ind. Com. e Exp S/A, Bebedouro-SP.

\subsection{Characterization of oleoresins}

Oleoresin samples were analyzed for their Antioxidant Activity (AA) and quantification of total phenolic compounds in duplicate. For these analyses, the lipid portion of oleoresins was separated using the procedure described by Parry et al. (2005).

The AA evaluation was performed by spectrophotometric determination based on the oxidation of $\beta$-carotene induced by products of oxidative fatty acid degradation (linoleic acid), according to the procedure described by Marco (1968) and modified by Miller (1971). In this analysis, the oleoresins were standardized in $0.5 \mathrm{mg} \cdot \mathrm{mL}^{-1}$ of methanol. BHT (100 mg.mL $\left.\mathrm{mL}^{-1}\right)$ was used as standard and the spectrophotometric measurements were done at $470 \mathrm{~nm}$ for 2 hours, every 20 minutes.

Total phenolic compounds were quantified by spectrophotometry using the Folin-Ciocalteu reagent (SINGLETON; ROSSI JUNIOR, 1965). For their quantification, gallic acid was used as standard at concentrations from 0 to $500 \mathrm{mg} \cdot \mathrm{mL}^{-1}$. The calibration curve equation obtained was $y=0.0016 x+0.00057$ with a correlation coefficient of 0.9995 . The contents of total phenolic compounds were expressed in milligrams of gallic acid equivalents for $100 \mathrm{~g}$ of oleoresin.

\subsection{Application of oleoresins}

Oleoresins were added to the soybean oil at the concentrations of $500,1000,1500,2000,2500$, and $3000 \mathrm{mg} \cdot \mathrm{kg}^{-1}$. A soybean oil free of antioxidants was used as control. The experiment was performed in three repetitions.

The antioxidant potential of oleoresins applied to soybean oil was evaluated by the determination of oxidative stability, using a Rancimat, model 743 Metrohm, an American... official method Cd 12b-92 (1993). The determination was performed at $100{ }^{\circ} \mathrm{C}$, with an air flow of $20 \mathrm{~L} /$ hour, using $3 \mathrm{~g}$ of sample, and a volume of distilled water of $60 \mathrm{~mL}$ in the flasks containing electrodes.

\subsection{Statistical analysis}

The results were subjected to analysis of variance in a completely randomized design, a $3 \times 7$ factorial design, and the determination of the most effective concentrations were defined by polynomial regression (BANZATTO; KRONKA, 2006). Analyses of variance, polynomial regressions, and the Tukey test for the averages at 5\% were obtained using the ESTAT - System for Statistical Analysis, version 2.0, 1999, Brazil (UNIVERSIDADE..., 1999).

\section{Results and discussion}

In the first step of the study, the antioxidant activity was determined by the $\beta$-carotene/linoleic acid system in order to characterize the oleoresins of oregano, basil, and thyme. The results are described in Table 2.

In Table 2, it is possible to observe that the oleoresin of oregano presented an activity similar to that of thyme, which was similar to basil's. The synthetic antioxidant BHT, commercial standard, presented higher activity regarding the oleoresins to prevent peroxides formation.

Many authors have found high levels of antioxidant activity in different varieties of spices (CALUCCI et al., 2003; EXARCHOU et al., 2002; MARTÍNEZ-TOMÉ et al., 2001), especially for the essential oil (DORMAN; SURAI; DEANS, 2000;

Table 1. Constituents of oleoresins studied.

\begin{tabular}{lccc}
\hline \multirow{2}{*}{ Components } & \multicolumn{3}{c}{ Oleoresins (\%) } \\
\cline { 2 - 4 } & Oregano & Basil & Thyme \\
\hline Natural extract & $60-70$ & $56-66$ & $55-65$ \\
Canola oil & $30-40$ & $34-44$ & $35-45$ \\
Mono and diglycerides & - & - & $0-10$ \\
\hline Source: Kalsec $^{\circ}$ & & &
\end{tabular}

Table 2. Antioxidant Activity (AA) of the oleoresins using the $\beta$-carotene/linoleic acid system.

\begin{tabular}{cc}
\hline Treatments & AA (\%) \\
\hline Oregano & $54.78^{\mathrm{b}}$ \\
Basil & $41.32^{\mathrm{c}}$ \\
Thyme & $52.32^{\mathrm{bc}}$ \\
BHT $^{\star}$ & $89.33^{\mathrm{a}}$ \\
\hline
\end{tabular}

Mean $(\mathrm{n}=2)$; ${ }^{*}$ Concentration of BHT, $100 \mathrm{mg} \cdot \mathrm{kg}^{-1}$, used for comparison; a, b..: different letters represent statistical differences $(\mathrm{p}<0.05)$. 
RUBERTO et al., 2002). In some studies, the extract of oregano (5\%) has shown to be more effective than the propyl gallate, BHT, and BHA at $100 \mu \mathrm{g} \cdot \mathrm{g}^{-1}$ (MARTÍNEZ-TOMÉ et al., 2001).

In the $\beta$-carotene/linoleic acid system, the samples were analyzed for 2 hours, and the spectrophotometric measurements were carried out at every 20 minutes in order to evaluate not only the total antioxidant activity by the end of the reaction, but also the behavior throughout the reaction time. From the data obtained, it was possible to describe the degradation kinetic curve of $\beta$-carotene and to evaluate the effectiveness of the antioxidant added in different time intervals. The kinetic curves of the oleoresins of oregano, basil, and thyme are presented in Figure 1.

The presence of antioxidants in the system protects the linoleic acid extending the period of formation of free radicals (HUANG; WANG, 2004). The smaller the decrease in the sample optical density, the more powerful the antioxidant capacity of inhibiting the degradation of $\beta$-carotene.

It is possible to observe that, generally, in curves of oleoresins the degradation occurs very similarly. At the beginning of the reaction (20 minutes), the oleoresin of oregano had a sharper decrease. However, at the end of the reaction (120 minutes), it protected the system better, followed by the oleoresin of thyme. It is also possible to observe a sharper decease in the oleoresin of basil after 100 minutes of reaction, which differs from the other oleoresins.

Table 3 shows the total phenolic contents of oleoresins of oregano, basil, and thyme. It is possible to verify that there was a great variation in the content of total phenolic compounds of the oleoresins. The oleoresins of thyme and oregano are the best sources of phenolic compounds.

Katalinic et al. (2006), investigating 70 samples of medicinal plants, measured the concentration of phenolic compounds using the Folin-Ciocalteau method. Among the samples, they analyzed thyme, and found $87.6 \mathrm{mg}$ of gallic acid per gram of dried sample, higher than that found in this study.

The total of phenolic compounds in ethanolic and aqueous extracts of thyme was also evaluated by Mata et al. (2007) using the Folin-Ciocalteu method. The values found for the ethanolic and aqueous extracts were 113 and $74.9 \mathrm{mg}$ of gallic acid per gram of sample, respectively.

The extraction of phenolic compounds from natural products is strongly influenced by the solvent used. It has been observed that the greater the polarity of the extraction solvent, the greater the amount of phenolic compounds extracted (GÁMÉZ-MEZA et al., 1999). In the present study, the solvents used for obtaining oleoresin are unknown.

These results indicate that the oleoresins of thyme and oregano are spices of high antioxidant capacity. Many authors have found a positive correlation between the quantity of total phenolics and the antioxidant capacity of foods (FALLARERO et al., 2003; KUSKOSKI et al., 2005).

However, it is known that besides phenolic compounds, vegetables contain other oxidation inhibitors, such as ascorbic acid, hydroxycarboxylic acids, and carotenoids that can also be extracted according to the polarity of the solvent applied (POKORNY, 2007) and, consequently, can be applied in vegetable oils.

In the second step, this study focused on indicating the most effective spices - among the three varieties being studied - when added to soybean oil, as well as the best concentration and possible pro-oxidant action.

The concentrations applied to the oleoresins, from 500 to $3000 \mathrm{mg} \cdot \mathrm{kg}^{-1}$, were defined in preliminary tests. The maximum limit determined was $3000 \mathrm{mg} . \mathrm{kg}^{-1}$ due to sensory alterations. It is worth to highlight that the oleoresins studied presented from 30 to $45 \%$ of canola oil (Table 1) in their composition. This is directly related to the increase in the concentration to be applied.

Table 4 presents the results of the oxidative stability averages for the treatments studied.

According to Table 4, it is possible to observe that among the oleoresins studied, the one that presented the greatest oxidative stability was the oleoresin of oregano, followed by

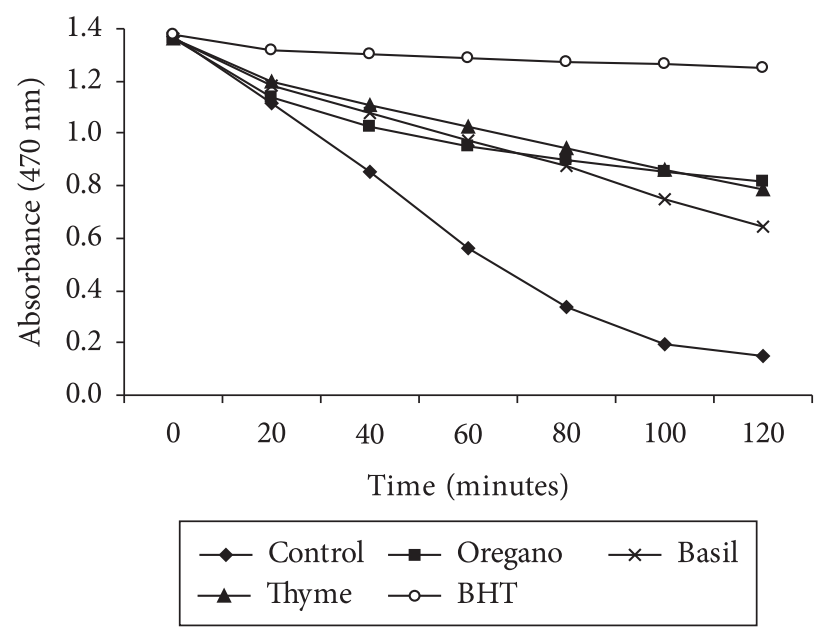

Figure 1. Kinetic curves of the antioxidant potential of the oleoresin $\beta$-carotene/linoleic acid system.

Table 3. Total phenolic contents expressed in mg equivalent of gallic acid per $100 \mathrm{~g}$ of oleoresin.

\begin{tabular}{cc}
\hline Treatments & Total phenolic contents $\left(\mathbf{m g} .100 \mathbf{g}^{-1}\right)$ \\
\hline Oregano & $25.93^{\mathrm{b}}$ \\
Basil & $6.18^{\mathrm{c}}$ \\
Thyme & $64.77^{\mathrm{a}}$ \\
\hline
\end{tabular}

Mean $(n=2)$; $a$, b..: different letters represent statistical differences $(\mathrm{p}<0.05)$.

Table 4. Oxidative stability averages (hours) for different concentrations of oleoresins.

\begin{tabular}{lccccccc}
\hline Treatments & \multicolumn{7}{c}{ Concentrations $\left(\mathbf{m g . k g} \mathbf{k g}^{-\mathbf{1}}\right)$} \\
\cline { 2 - 7 } & $\mathbf{0}$ & $\mathbf{5 0 0}$ & $\mathbf{1 0 0 0}$ & $\mathbf{1 5 0 0}$ & $\mathbf{2 0 0 0}$ & $\mathbf{2 5 0 0}$ & $\mathbf{3 0 0 0}$ \\
\hline OS + OO & $10.44^{\mathrm{eA}}$ & $12.08^{\mathrm{dA}}$ & $12.82^{\mathrm{dA}}$ & $13.89^{\mathrm{cA}}$ & $14.95^{\mathrm{bA}}$ & $15.20^{\mathrm{abA}}$ & $16.16^{\mathrm{aA}}$ \\
$\mathrm{OS}+\mathrm{OB}$ & $10.44^{\mathrm{bA}}$ & $11.32^{\mathrm{abB}}$ & $11.21^{\mathrm{ab}}$ & $10.50^{\mathrm{bC}}$ & $11.14^{\mathrm{abC}}$ & $10.52^{\mathrm{bC}}$ & $11.56^{\mathrm{aC}}$ \\
OS + OT & $10.44^{\mathrm{eA}}$ & $11.38^{\mathrm{deAB}}$ & $11.63^{\mathrm{cdB}}$ & $12.46^{\mathrm{bB}}$ & $12.80^{\mathrm{bB}}$ & $13.01^{\mathrm{bB}}$ & $14.01^{\mathrm{aB}}$ \\
\hline OS: soybean oil; OO: oleoresin oregano; OB: oleoresin basil; OT: oleoresin thyme; \\
Statistical (p < 0.05) difference between treatments (column) and within treatments \\
(rows) are represented as upper and lower case letters, respectively. Different letters \\
represent statistical differences.
\end{tabular}


thyme and basil. The general averages were $13,65^{\mathrm{a}}, 12,25^{\mathrm{b}}$ and $10,96^{c}$, respectively. The difference was statistically evidenced according to the Tukey test $(\mathrm{p}<0.05)$.

When evaluating the concentrations studied, it is possible to verify that the oleoresins presented a protective effect against lipid oxidation when compared to the control, given that in the oleoresins of oregano and thyme, the oxidative stability was directly proportional to the increase of concentration. When calculating the percentage of increase in the induction period, in relation to the control (soybean oil free of antioxidants), in the final concentration of $3000 \mathrm{mg} \cdot \mathrm{kg}^{-1}$, oregano presented an oxidation inhibition percentage of $54.79 \%$, followed by thyme with $34.20 \%$ and basil with only $10,73 \%$.

Moreira and Mancini-Filho (2003), evaluating spices extracts mustard, cinnamon, and anise quantified a protection of $19.63 \%$ for the aqueous extract of mustard seeds, which presented the greatest protection of oxidation in the soybean oil free of antioxidant (among the samples tested).

The increase in the induction period by the addition of an antioxidant has been related to the antioxidant effectiveness, and it can be expressed as a protection factor or antioxidant index. In other words, it is the ratio between the induction period of an oil in the presence of an antioxidant and the induction period of the same oil in the absence of the antioxidant (HOLASOVA et al., 2006; MEZOUARI; EICHNER, 2007). In addition, the greater the protection factor, the better the antioxidant activity (ELIZABLE; BRESSA; ROSA, 1992).

Table 5 shows the protection factors for all concentrations of oleoresins studied.

All oleoresins presented a protection factor greater than 1 , protection factor of the control; however, the oleoresin of oregano deserves special attention since it was more effective in delaying oxidation under all concentrations applied.

In order to better define the concentration between the two most effective oleoresins, oregano and thyme, analyses of variance were applied by polynomial regression with data of the oxidative stability. Through the polynomial regression (Figure 2), it is possible to observe that the values of oxidative stability increased as concentrations increased for both oleoresins, without evidencing any pro-oxidant effect. The following first degree equations were obtained for the oleoresin of oregano: $y=0.0018 x+10.913$ and for the oleoresin of thyme: $y=0.011 x+10.625$, respectively, where $y$ represents the Oxidative Stability (hours), and $\times$ represents the Concentrations (mg. $\mathrm{kg}^{-1}$ ).

Concerning the oleoresin of oregano, the coefficient of determination of the linear regression $\left(R^{2}=0.9739\right)$ was higher than 0.9. Therefore, it could be used to explain the behavior of this oleoresin (Figure 2).

As for the oleoresin of thyme, the linear regression was significant $(\mathrm{p}<0.01)$, and it also presented a coefficient $\left(\mathrm{R}^{2}=0.9708\right)$ higher than 0.9 (Figure 2 ). It is possible to verify that a relationship between oxidative stability and concentrations of oleoresins in soybean oil can be established. The lines indicate an increasing oxidant action as the concentrations increase, in other words, as the concentration of oleoresin increases in the oil, the oxidative stability tends to increase.
Table 5. Protective factors for oleoresins applied in soybean oil.

\begin{tabular}{lcccccc}
\hline Treatments & \multicolumn{6}{c}{ Concentrations $\left(\mathbf{m g .} \mathbf{k g}^{-1}\right)$} \\
\cline { 2 - 7 } & $\mathbf{5 0 0}$ & $\mathbf{1 0 0 0}$ & $\mathbf{1 5 0 0}$ & $\mathbf{2 0 0 0}$ & $\mathbf{2 5 0 0}$ & $\mathbf{3 0 0 0}$ \\
\hline OS + OO & 1.16 & 1.23 & 1.33 & 1.43 & 1.46 & 1.55 \\
OS + OB & 1.08 & 1.07 & 1.01 & 1.07 & 1.01 & 1.11 \\
OS + OT & 1.09 & 1.11 & 1.11 & 1.19 & 1.25 & 1.34
\end{tabular}

OS: soybean oil; OO: oleoresin oregano; OB: oleoresin basil; OT: oleoresin thyme.

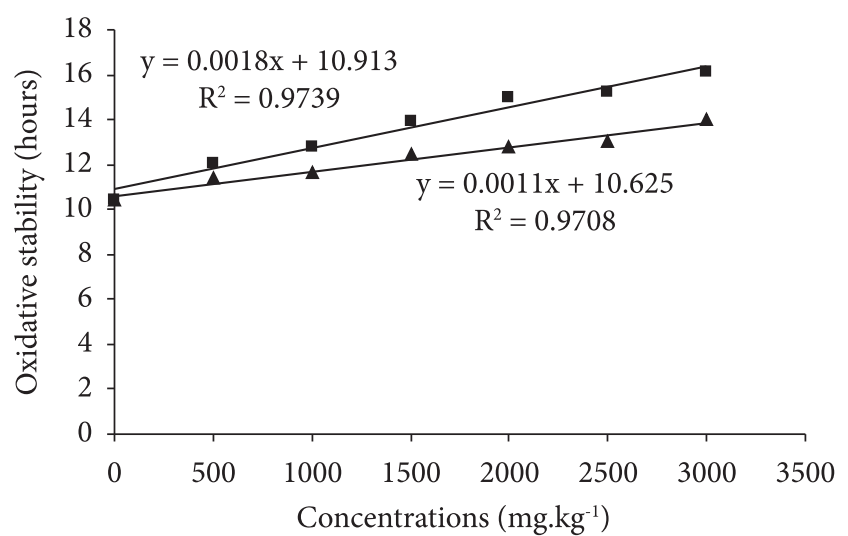

Figure 2. Oxidative stability of soybean oil under different concentrations of oregano and thyme oleoresins.

In general, the same characteristics are found in the literature regarding the antioxidant activity of natural extracts, i.e. as the concentration of the extract increases, the antioxidant activity also tends to increase (AZIZAH; RUSLAWATI; TEE, 1999; LEE; KIM; ASHMORE, 1986).

Based on the oxidative stability and on the protection factor found, the most effective oleoresins were those of oregano and thyme, respectively. And through polynomial regression, the most effective concentration regarding the delay of lipid oxidation was $3000 \mathrm{mg} \cdot \mathrm{kg}^{-1}$ for both oleoresins.

\section{Conclusions}

The oleoresins studied presented antioxidant potential, given that the content of total phenolic compounds and the antioxidant activity by the $\beta$-carotene/linoleic acid system were higher in the oleoresins of thyme and oregano. These oleoresins provided greater oxidative stability when applied to soybean oil. The application of oleoresins of oregano and thyme at a concentration of $3000 \mathrm{mg} \cdot \mathrm{kg}^{-1}$ is recommended instead of synthetic antioxidants.

\section{References}

AMERICAN OIL CHEMISTS SOCIETY - AOCS. Official methods and recommended practices of the American Oil Chemists' Society. Champaign: AOCS, 1993.

ANDREO, D.; JORGE, N. Avaliação da capacidade antioxidante do extrato de gengibre (Gengiber officinale) adicionado ao óleo de soja em teste de estocagem acelerada. Revista do Instituto Adolfo Lutz, v. 66, n. 2, p. 152-157, 2007.

ANGELO, P. M.; JORGE, N. Antioxidant evaluation of coriander extract and ascorbyl palmitate in sunflower oil under thermoxidation. Journal of the American Oil Chemists' Society, v. 85, n. 11, p. 1045-1049, 2008. 
AZIZAH, A. H.; RUSLAWATI, N. M. N.; TEE, T. S. Extraction and characterization of antioxidant from cocoa by-products. Food Chemistry, v. 64, n. 2, p. 199-202, 1999. http://dx.doi.org/10.1016/ S0308-8146(98)00121-6

BANZATTO, D. A., KRONKA, s. N. Experimentação agrícola. 4. ed. Jaboticabal: Funep, 2006. 237 p.

BRASIL. Resolução RDC n 23/2005, de 15 de fevereiro de 2005. Regulamento Técnico de Aditivos Alimentares para Óleos e Gorduras. Diário Oficial da República Federativa do Brasil, Brasília, DF, 16 fev. 2005. Secção I.

CALUCCI, L. et al. Effects of $\gamma$-irradiation on the free radical and antioxidant contents in nine aromatic herbs and spices. Journal of Agricultural and Food Chemistry, v. 51, n. 4, p. 927-934, 2003. PMid:12568551. http://dx.doi.org/10.1021/jf020739n

DORMAN, H. J. D.; SURAI, P.; DEANS, S. G. In vitro antioxidant activity of a number of plant essential oils and phytoconstituents. The Journal of Essential Oil Research, v. 12, n. 2, p. 241-248, 2000.

ELIZABLE, B. E.; BRESSA, F; ROSA, M. D. Antioxidative action of maillard reactions volatiles: influence of maillard solution level. Journal of the American Oil Chemists' Society, v. 69, n. 3, p. 331-334, 1992.

EXARCHOU, V. et al. Antioxidant activities and phenolic composition of extracts from greek oregano, greek sage, and summer savory. Journal of Agricultural and Food Chemistry, v. 50, n. 19, p. 52945299, 2002. PMid:12207464. http://dx.doi.org/10.1021/jf020408a

FALLARERO, A. et al. Effects of aqueous extracts of Halimeda incrassata (Ellis) Lamouroux and Bryothamnion trquetrum (S.G. Gmelim) howe on hydrogen peroxide and methyl mercury-induced oxidative stress in GT1-7 mouse hypothalamic immortalized cells. Phytomedicine, v. 10, n. 1, p. 39-47, 2003. PMid:12622462. http:// dx.doi.org/10.1078/094471103321648647

GÁMEZ-MEZA, n. et al. Antioxidant activity in soybean oil of extract from Thompson grape bagasse. Journal of the American Oil Chemists' Society, v. 76, n. 12, p.1445-1447, 1999.

GUNDUC, N. ; EL, S. N. Assessing antioxidant activities of phenolic compounds of common Turkisch food and drinks on in vitro lowdensity lipoprotein oxidation. Journal of Food Science, v. 68, n. 8, p. 2591-2595, 2003. http://dx.doi.org/10.1111/j.1365-2621.2003. tb07066.x

HOLASOVA, M. et al. Buckwheat - the source of antioxidant activity in functional foods. Food Research International, v. 35, n. 2, p. 207-211, 2006. http://dx.doi.org/10.1016/S0963-9969(01)00185-5

HUANG, L. H.; WANG, B. G. Antioxidant capacity and lipophilic content of seaweeds collected from the qingdao coastline. Journal of Agricultural and Food Chemistry, v. 52, n. 16, p. 4993-4997, 2004. PMid:15291465. http://dx.doi.org/10.1021/jf049575w

KATALINIC, V. et al. Screening of 70 medicinal plant extracts for antioxidant capacity and total phenols. Food Chemistry, v. 94, n. 4, p. 550-557, 2006. http://dx.doi.org/10.1016/j.foodchem.2004.12.004

KIKUZAKI, H.; NAKATANI, N. Structure of a new antioxidative phenolic acid from oregano (Oreganum vulgare L). Agricultural and Biological Chemistry, v. 53 , n. 6 , p. 519-524, 1989. http:// dx.doi.org/10.1271/bbb1961.53.519

KUSKOSKI, E. M. et al. Aplicación de diversos métodos químicos para determinar actividad antioxidante en pulpa de frutos. Ciência e Tecnologia de Alimentos, v. 25, n. 4, p. 726-732, 2005. http:// dx.doi.org/10.1271/bbb1961.53.519

LEE, S. J. et al. Identification of volatile components in basil (Ocimum basilicum L.) and thyme leaves (Thymus vulgaris L.) and their antioxidant properties. Food Chemistry, v. 91, n. 1, p. 131137, 2005. http://dx.doi.org/10.1016/j.foodchem.2004.05.056

LEE, Y. B.; KIM, Y. S.; ASHMORE, C. R. Antioxidant properties in ginger rhizome and its application to meat products. Journal of Food Science, v. 51, n. 1, p. 20-23, 1986. http://dx.doi. org/10.1111/j.1365-2621.1986.tb10826.x

MARCO, G. J. A rapid method for evaluation of antioxidants. Journal of the American Oil Chemists' Society, v. 45, n. 6, p. 594-598, 1968.
MARTÍNEZ-TOMÉ, M. et al. Antioxidant properties of Mediterranean spices compared with common food additives. Journal of Food Protection, v. 64, n. 9, p 1412-1419, 2001.

MATA, A. T. et al. Antioxidant and antiacetylcholinesterase activities of five plants used as Portuguese food spices. Food Chemistry, v. 103, n. 3, p. 778-786, 2007. http://dx.doi.org/10.1016/j.foodchem.2006.09.017

MELO, E. A. et al. Atividade antioxidante de extratos de coentro (Coriandrum sativum L.). Ciência e Tecnologia de Alimentos, v. 23 , n. 1, p. 195-199, 2003. http://dx.doi.org/10.1590/S010120612003000400036

MEZOUARI, S.; EICHNER, K. Evaluation of the stability of blends of sunflower and rice bran oil. European Journal of Lipid Science and Technology, v. 109, n. 5, p. 531-535, 2007. http://dx.doi.org/10.1002/ ejlt.200600217

MILLER, H. E. A simplified method for the evaluation of antioxidants. Journal of the American Oil Chemists' Society, v. 48, n. 2, p. 91, 1971.

MILOS, M.; MASTELIC, J.; JERKOVIC, I. Chemical composition and antioxidant e.ect of glycosidically bound volatile compounds from oregano (Origanum vulgare L. ssp. hirtum). Food Chemistry, v. 71, n. 1, p. 79-83, 2000. http://dx.doi.org/10.1016/S0308-8146(00)00144-8

MOREIRA, A. V. B.; MANCINI-FILHO, J. Atividade antioxidante das especiarias mostarda, canela e erva-doce, em sistemas aquoso e lipídico. Nutrire, v. 25, n.1, p. 31-46, 2003.

MURCiA, M. A.; JIMÉNEZ, A. M.; MANTÍNEZ-TOMÉ, M. Evaluation of the antioxidant properties of Mediterranean and tropical fruits compared with common food additives. Journal of Food Protection, v. 64, n. 12, p. 2037-2046, 2001.

NAWAR, W. W. Lipids. In: FENNEMA, O. R. Food Chemistry. 3. ed. New York: Marcel Dekker, 1996. p. 225-319.

PARRY, J. et al. Fatty acid composition and antioxidant properties of cold-pressed marionberry, boysenberry, red raspberry, and blueberry seed oils. Journal of Agricultural and Food Chemistry, v. 53, n. 3, p. 566-573, 2005. PMid:15686403. http://dx.doi. org/10.1021/jf048615t

POKORNY, J. Are natural antioxidants better - and safer - than synthetic antioxidants? European Journal of Lipid Science and Technology, v. 108, n. 6, p. 629-642, 2007. http://dx.doi.org/10.1002/ejlt.200700064

RAMALHO, V. C.; JORGE, N. Atividade antioxidante do $\alpha$-tocoferol e do extrato de alecrim em óleo de soja purificado. Revista do Instituto Adolfo Lutz, v. 65, n. 1, p.15-20, 2006.

RUBERTO, G. et al. Chemical composition and antioxidant activity of essential oils from Algerian Origanum glandulosum Desf. Flavour and Fragrance Journal, v. 17, n. 4, p. 251-254, 2002. http://dx.doi. org/10.1002/ff. 1101

SILVA, F. A. M.; BORGES, M. F. M.; FERREIRA, M. A. Métodos para avaliação do grau de oxidação lipídica e da capacidade antioxidante. Química Nova, v. 22, n. 1, p. 94-103, 1999. http:// dx.doi.org/10.1590/S0100-40421999000100016

SINGLETON, V. L.; ROSSI JUNIOR, J. A. Colorimetry of total phenolics with phosphomolybdic-phosphotungstic acid reagents. American Journal of Enology and Viticulture, v. 16, n. 2, p. 144-158, 1965.

SVILAAS, A. et al. Intakes of antioxidants in coffee, and vegetables are correlated with plasma carotenoid in humans. Journal of Nutrition, v. 134, n. 3, p. 562-567, 2004.

UNIVERSIDADE ESTADUAL PAULISTA. Faculdade de Ciências Agrárias e Veterinárias. ESTAT - Sistema para Análises Estatísticas. Versão 2.0. Jaboticabal: UNESP, 1999.

VEKIAKI, S. A. et al. Oregano flavonoids as lipid antioxidants. Journal of the American Oil Chemists Society, v. 70, n. 5, p. 483-487,1993. http://dx.doi.org/10.1007/BF02542580

WANASUNDARA, U. N.; SHAHIDI, F. Antioxidant and pro-oxidant activity of green tea extracts in marine oils. Food Chemistry, v. 63, n. 3 , p. 335-342, 1998. http://dx.doi.org/10.1016/S0308-8146(98)00025-9 